\title{
THE EFFECT OF LONGSHORE TOPOGRAPHIC VARIATION ON OVERWASH MODELLING
}

\author{
Robert McCall ${ }^{1}$, Nathaniel Plant ${ }^{2}$ and Jaap van Thiel de Vries ${ }^{1}$
}

\begin{abstract}
This paper describes an application of the XBeach model to investigate the effect of longshore topographic variance on overwash. The model is used to simulate the morphological response of an eight-kilometer section of Santa Rosa Island, Florida, due to Hurricane Ivan (2004). The influence of longshore scales in the bed elevation is investigated by comparing the morphological response of the reference simulation to the morphological response of six sensitivity simulations in which the initial bed elevation was modified to remove longshore topographic variance. It is shown that the morphological response of the foreshore-foredune area to Hurricane Ivan is not influenced strongly by the initial longshore bed variance. The morphological response of the back barrier and the back barrier bay to Hurricane Ivan is influenced by features on the back barrier with longshore length scales of 100-500 meters, which hamper the flow across the island during inundation overwash. It is noted that these results may vary for other overwash regimes.
\end{abstract}

Keywords: overwash, washover, topographic variance, longshore variance, morphodynamic modeling, XBeach

\section{INTRODUCTION}

For most barrier coasts, overwash constitutes a natural response to increased hydraulic forcing by storm surge and waves. Overwash contributes to the sediment budget of barrier islands and is thought to help maintain the width of barrier islands as they migrate landwards (e.g. Godfrey and Godfrey, 1973; Hosier and Cleary, 1977). In developed areas, overwash can be hazardous as it may lead to a reduction of the dune height and subsequent breaching of the dunes, and potentially loss of life (Donnelly et al., 2006). Field studies have shown that overwash is highly influenced by spatial variations in forcing and topography such that it will exploit existing gaps and low lying areas in the foredune line (e.g. Dolan and Hayden, 1981; Suter et al., 1982).

Insight into the spatial variation of overwash and quantitative predictions thereof would greatly improve the ability of coastal managers to assess the safety of the coast and to evaluate maintenance and mitigation strategies. One of the key questions in this regard is what the relative importance is of small-scale longshore features in the bed elevation compared to the importance of large-scale features in determining overwash.

In this paper we investigate the importance of features with various longshore scales on the pattern and magnitude of overwash. This is achieved using a new process-based model for the nearshore and coast developed by Roelvink et al. (2009) called XBeach. The XBeach model has already been shown to accurately reproduce spatially-varying overwash response on Santa Rosa Island, Florida, during Hurricane Ivan (McCall et al., 2010) which lends confidence that it is a useful tool to answer subsequent questions.

Using the XBeach model we simulate overwash on an eight-kilometer stretch of Santa Rosa Island, Florida, caused by Hurricane Ivan (2004). The influence of longshore spatial scales on overwash is examined by re-simulating the Hurricane event using an initial bed in which variance at given longshore scales has been removed.

The paper starts with a description of Hurricane Ivan and the study area (next section). The following sections describe the XBeach model formulation and the set-up of the XBeach model for this study. The model results and the conclusions are described in the final sections of this paper.

\footnotetext{
${ }^{1}$ Deltares (formerly Delft Hydraulics), P.O. Box 177, $2600 \mathrm{MH}$ Delft, The Netherlands

${ }^{2}$ Center for Coastal \& Watershed Studies, USGS, St. Petersburg, Florida, USA
} 


\section{HURRICANE IVAN AND SANTA ROSA ISLAND}

Hurricane Ivan was the largest of five hurricanes to strike the US coast in 2004, ranking as the tenth most powerful Atlantic hurricane on record. Hurricane Ivan made landfall at 06:50 UTC on 16 September just east of Mobile Bay, Alabama, as a category 3 hurricane on the Saffir-Simpson scale.

Santa Rosa Island, Florida, is a wave dominated, narrow barrier island between the Gulf of Mexico and the Santa Rosa Sound on the Northern Florida Panhandle. The island is aligned approximately east-west and has a length of roughly 85 kilometers. The width of the island varies between 150 and 1000 meters. The western-most tip of the island is approximately 50 kilometers from the location of landfall of Hurricane Ivan, see Figure 1. During Hurricane Ivan, large stretches of Santa Rosa Island were overwashed. Overwash deposit depths up to 1.5 meters and multiple breaches occurred on the western-most tip (Department of Environmental Protection State of Florida, 2004).

The study area in this paper, an eight-kilometer stretch of Santa Rosa Island between Pensacola Beach and Navarre Beach, which is part of the Gulf Islands National Seashore, is indicated by the red rectangle in Figure 1 and Figure 2.
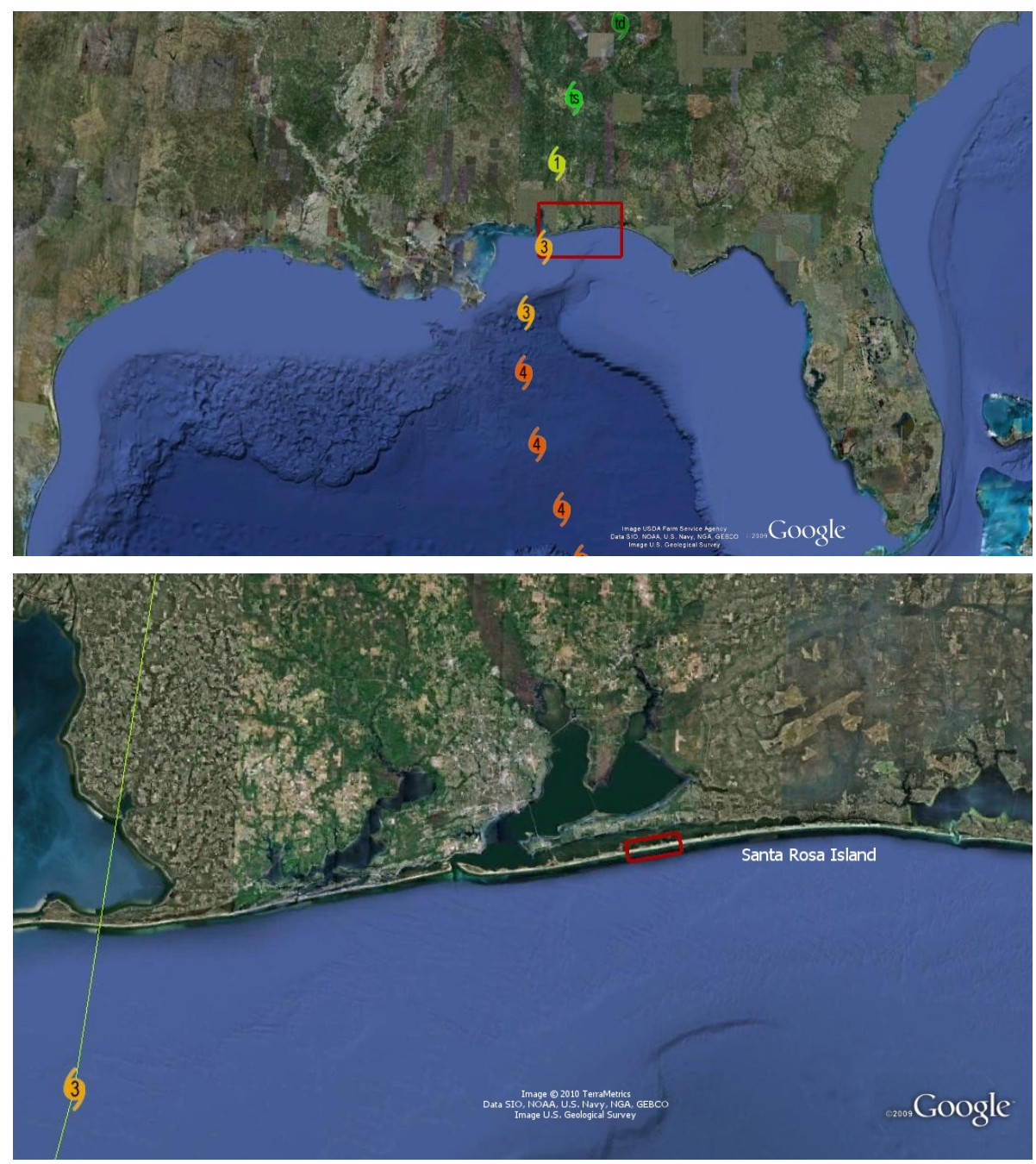

Figure 1: Track and intensity of Hurricane Ivan based on data from NOAA National Weather Service. The area in the red box in the top panel box is shown in the bottom panel. The area in the red box in the bottom panel represents the study area. Images courtesy of Google Earth ${ }^{\mathrm{TM}}$ mapping service. 


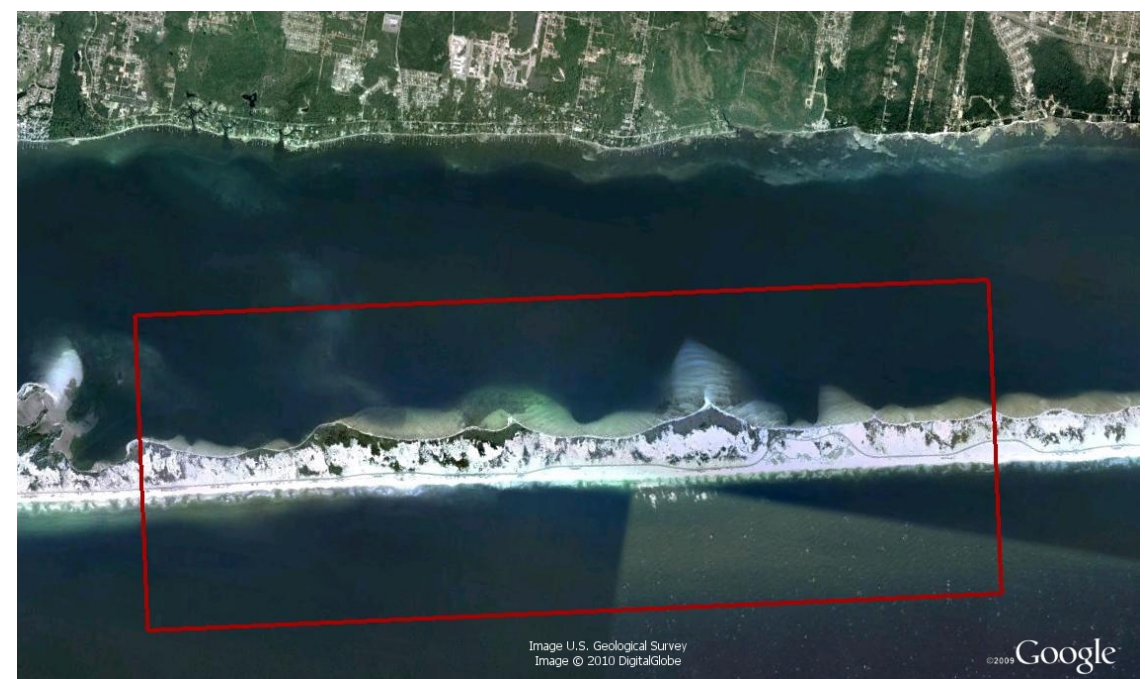

Figure 2: March 2004 aerial photo of the study area. The area in the red box indicates the model domain. Image courtesy of Google Earth ${ }^{\mathrm{TM}}$ mapping service.

\section{Pre- and post-storm bathymetric and altimetric data}

Two LIDAR (Light Detection and Ranging, Brock et al., 2002) surveys of the study area carried out on 15 May 2004 and 19 September 2004 provide high resolution pre- and post-storm bathymetry and altimetry data of the study area. The LIDAR measurements prior to Hurricane Ivan span most of the width of Santa Rosa Island and much of the nearshore. Pre-storm bathymetry data of the back bay area are provided by the NGDC Coastal Relief Model (Divins and Metzger, 2008), see Figure 4 (top panel). Post Hurricane Ivan LIDAR data are less complete than the pre-storm data. Only one swath was made in order to quickly assess the state of the dunes. Much of the bay side of the island was not surveyed, along with the nearshore on the Gulf side; see Figure 4 (center panel). Analysis of the preand post-storm data reveals patterns of erosion and deposition which are mainly due to the smoothing of the initially irregular profile during the storm. These patterns are shown in Figure 4 (bottom panel).
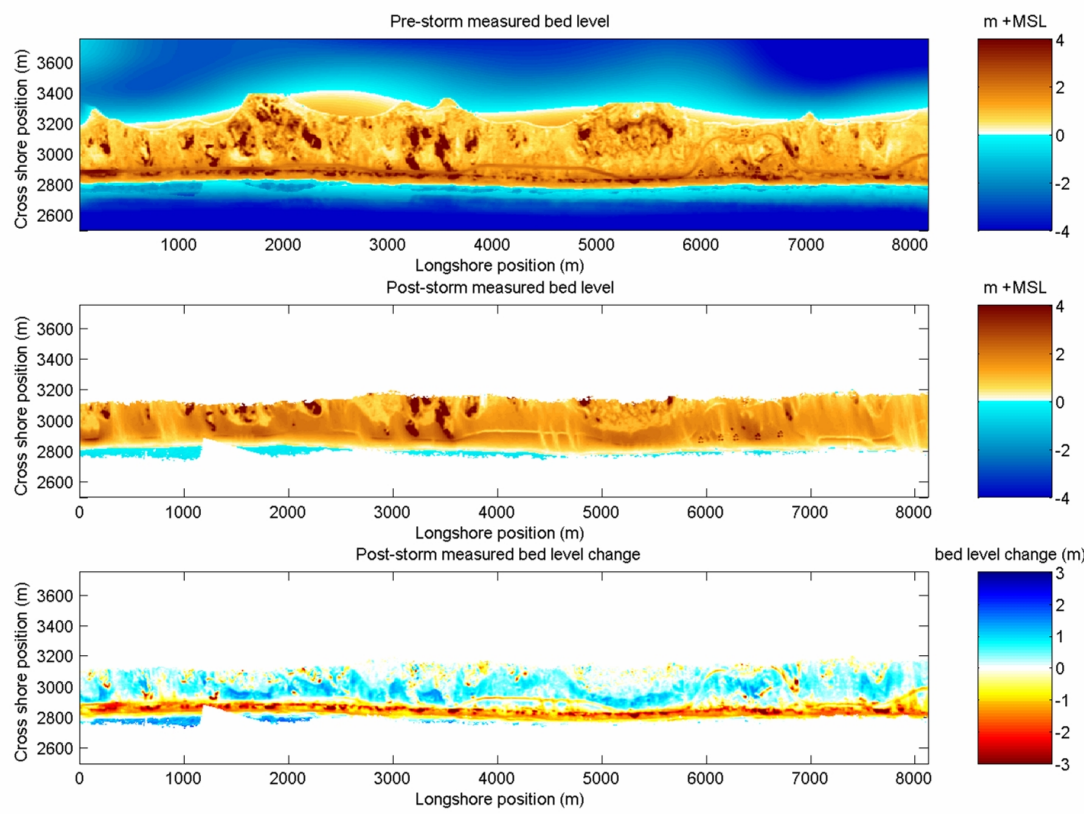

Figure 3: LIDAR/NGDC Coastal Relief Model pre-storm bed elevation of the study site (top panel), LIDARmeasured post-storm bed elevation of the study site (center panel) and areas of erosion (red) and deposition (blue) calculated from the measured pre- and post-storm data (bottom panel). 


\section{XBEACH DESCRIPTION}

$\mathrm{XBeach}$ is a $2 \mathrm{DH}$ (depth averaged) model that solves coupled short wave energy, flow and infragravity wave propagation, sediment transport and bed level change. The model has a robust numerical scheme (Stelling and Duinmeijer, 2003), allowing it to simulate flooding and drying, thereby removing the need for separate dry and wet domains and procedures. A brief description of the model is given below. A more comprehensive description is given by Roelvink et al. (2009).

\section{Model formulations}

XBeach solves the time-dependent short wave action balance on the scale of wave groups. The directional distribution of the short wave action density spectrum is taken into account in the model, whereas the frequency domain is represented by a single representative peak frequency, assuming a narrow banded incident spectrum (c.f. Goda, 1985). This approach is similar to the $2^{\text {nd }}$ generation spectral HISWA model (Holthuijsen et al., 1989), but includes time-dependency. Using these wave action formulations it is possible to solve directionally-spread infragravity waves and time-varying currents, as will be described below.

The wave action balance is given as follows:

$$
\frac{\partial A}{\partial t}+\frac{\partial c_{g, x} A}{\partial x}+\frac{\partial c_{g, y} A}{\partial y}+\frac{\partial c_{\theta} A}{\partial \theta}=-\frac{D_{\text {waves }}}{\sigma}
$$

Where $A=E / \sigma, E$ is the wave energy and $\sigma$ is the intrinsic wave frequency. The $\mathrm{x}$ - and y-velocities $\left(c_{g, x}, c_{g, y}\right)$ in equation (1) represent the respective components of the wave group velocity. The velocity in directional space $\left(c_{\theta}\right)$ takes into account refraction due to bottom and currents. The energy dissipation due to wave breaking, $D_{\text {waves }}$, is modeled according Roelvink (1993). XBeach includes a roller energy balance in order to redistribute energy from breaking waves to foam. Dissipation of short wave energy is used as a source term in the roller energy balance:

$$
\frac{\partial E_{\text {roller }}}{\partial t}+\frac{\partial c_{x} E_{\text {roller }}}{\partial x}+\frac{\partial c_{y} E_{\text {roller }}}{\partial y}+\frac{\partial c_{\theta} E_{\text {roller }}}{\partial \theta}=-D_{\text {roller }}+D_{\text {waves }}
$$

Roller energy dissipation is calculated according to Reniers (1999), following Deigaard (1993) and Svendsen (1984).

Surface elevation and flow, including infragravity waves and unsteady wave-induced currents, are solved using the shallow water momentum and mass balance equations. To include short wave-induced mass fluxes and return flows in shallow water, XBeach uses the Generalized Lagrangian Mean formulation (Andrews and McIntyre, 1978). The depth-average GLM-shallow water equations are given as follows:

$$
\begin{aligned}
\frac{\partial u^{L}}{\partial t}+ & u^{L} \frac{\partial u^{L}}{\partial x}+v^{L} \frac{\partial u^{L}}{\partial y}-v_{h}\left(\frac{\partial^{2} u^{L}}{\partial x^{2}}+\frac{\partial^{2} u^{L}}{\partial y^{2}}\right)= \\
& -g \frac{\partial \eta}{\partial x}-\frac{c_{f} u^{E} \sqrt{\left(1.16 u_{r m s}\right)^{2}+\left(u^{E}\right)^{2}+\left(v^{E}\right)^{2}}}{h}+\frac{F_{x}}{\rho h} \\
\frac{\partial v^{L}}{\partial t}+v^{L} \frac{\partial v^{L}}{\partial y}+u^{L} \frac{\partial v^{L}}{\partial x}-v_{h}\left(\frac{\partial^{2} v^{L}}{\partial y^{2}}+\frac{\partial^{2} v^{L}}{\partial x^{2}}\right)= & -g \frac{\partial \eta}{\partial y}-\frac{c_{f} v^{E} \sqrt{\left(1.16 u_{r m s}\right)^{2}+\left(u^{E}\right)^{2}+\left(v^{E}\right)^{2}}}{h}+\frac{F_{y}}{\rho h} \\
\frac{\partial \eta}{\partial t}= & -\frac{\partial u^{L} h}{\partial x}-\frac{\partial v^{L} h}{\partial y}
\end{aligned}
$$


L- and E-indexes for the $x(u)$ and $y(v)$ velocities refer to Lagrangian and Eulerian framework. Water depth is denoted by $h$, the water surface elevation by $\eta$ and the bed friction coefficient by $c_{f}$. The horizontal viscosity coefficient $\left(v_{h}\right)$ is modified by wave breaking in the surf zone, following Reniers et al. (2004). Bed friction is calculated using the parameterization of Feddersen et al. (2000). The wave and roller forcing terms $\left(F_{x}, F_{y}\right)$ in (3) and (4) are calculated from the short wave radiation stress gradients in $\mathrm{x}$ - and $\mathrm{y}$-direction, which are functions of the wave and roller energies.

Sediment transport rates are calculated as:

$$
\begin{aligned}
& S_{x}=h C u^{E}-D_{s} h \frac{\partial C}{\partial x} \\
& S_{y}=h C v^{E}-D_{s} h \frac{\partial C}{\partial y}
\end{aligned}
$$

in which $C$ is the depth-averaged sediment concentration and $D_{s}$ is the sediment diffusion coefficient. Sediment concentrations in the water column are modeled using a depth-averaged advection-diffusion scheme with a source-sink term based on an equilibrium sediment concentration (Galapatti and Vreugdenhil, 1985):

$$
\frac{\partial h C}{\partial t}+\frac{\partial h C u^{E}}{\partial x}+\frac{\partial h C v^{E}}{\partial y}+\frac{\partial}{\partial x}\left(D_{s} h \frac{\partial C}{\partial x}\right)+\frac{\partial}{\partial y}\left(D_{s} h \frac{\partial C}{\partial y}\right)=\frac{h C_{e q}-h C}{T_{s}}
$$

where $T_{s}$ is the sediment concentration adaptation time scale. The equilibrium concentration source-sink term $\left(C_{e q}\right)$ is calculated using the Soulsby-Van Rijn formulation (Soulsby, 1997):

$$
C_{e q}=\frac{A_{s b}+A_{s s}}{h}\left(\sqrt{\left(u^{E}\right)^{2}+\left(v^{E}\right)^{2}+0.018 \frac{u_{r m s}^{2}}{C_{d}}}-u_{c r}\right)^{2.4}
$$

in which $u_{c r}$ is the critical transport velocity based on Shields (see van Rijn, 1993), $C_{d}$ is the short wave related drag coefficient and $A_{s s}$ and $A_{s b}$ are suspended and bed load transport coefficients respectively. For high flow velocities, the stirring velocity in (8) is limited to a maximum based on the Shields number at the start of sheet flow (McCall et al., 2010).

Bed level change due to sediment transport rate gradients is assumed to occur on a time scale that is much longer than those associated with the hydrodynamic processes. Therefore, the time scale for the morphologic changes can be accelerated such that they take place at a rate that is still slower than the hydrodynamic processes, but occur rapidly enough to be relevant over a small number of hydrodynamic cycles. Thus:

$$
\frac{\partial z_{b}}{\partial t}=-\frac{f_{m o r}}{(1-p)}\left(\frac{\partial S_{x}}{\partial x}+\frac{\partial S_{y}}{\partial y}\right)
$$

In which $f_{m o r}$ is a morphological acceleration factor of $\mathrm{O}(1-10)$ and $p$ is the bed porosity.

XBeach uses an avalanching algorithm in order to simulate dune slumping during storm conditions. Avalanching occurs if the bed slope exceeds a prescribed critical value for wet or dry points, as extensively tested by Van Thiel de Vries (2009).

\section{MODEL SETUP}

In order to investigate the effect of varying longshore spatial scales on overwash, one reference simulation and six sensitivity simulations are carried out. In each sensitivity simulation the initial bed elevation is changed to filter out longshore variation in the bed at varying length scales. No filtering is applied in the cross shore direction. All simulations are carried out with identical boundary conditions. The numerical grid is constant for all simulations, with 10 meter grid spacing in the longshore direction 
and varying grid size in the cross shore direction. The model parameter settings applied by McCall et al. (2010) are used in all simulations.

\section{Initial bed elevation}

The initial bed level for the reference simulation is based on the pre-storm LIDAR and NGDC elevation data described in the previous section. These data are combined on the numerical model grid by means of scale-controlled interpolation (Plant et al., 2002). An analysis of the longshore bed elevation variance in the initial bed level for the reference simulation shows that variance on the barrier starts to increase at length scales greater than 50 meters, see Figure 4. On the barrier, length scales in the range between 300 and 1000 meters contribute strongly to the elevation pattern. The greatest longshore variance is located in the back barrier bay at length scales of over 1000 meters, which corresponds with the spacing of large-scale geomorphic features, including older washover fans on the back of the barrier island.

The initial bed elevations for the sensitivity simulations are found by applying a longshore moving-average filter on the reference bed. The longshore averaging distances for sensitivity simulations increase from 50 meters to 10,000 meters, see Table 1. Longshore filter lengths of 50 and 100 meters smooth small-scale features in the foredunes and on the back barrier, see Figure 5. The 500-meter longshore filter length smooths significant features in the subaerial barrier island. The 10000-meter longshore filter length leads to an essentially longshore-uniform bed level.
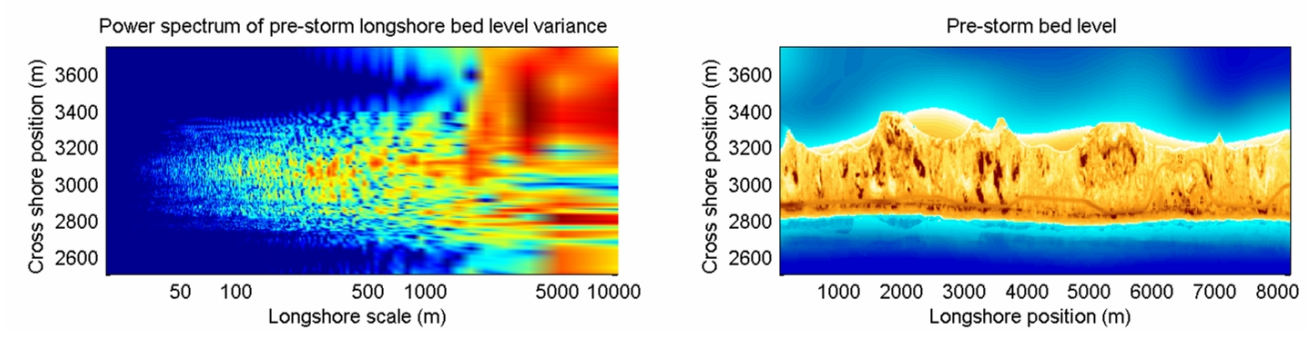

Figure 4: Power spectrum of the longshore bed level variance of the reference bed as function of the cross shore position and longshore length scales (left panel) and the initial bed level of the reference bed (right panel).

\begin{tabular}{|c|c|}
\hline \multicolumn{2}{|c|}{ Table 1: Simulation longshore filtering distances } \\
\hline Name & Longshore filtering distance \\
\hline Reference & $10 \mathrm{~m}$ \\
Sensitivity 1 & $50 \mathrm{~m}$ \\
Sensitivity 2 & $100 \mathrm{~m}$ \\
Sensitivity 3 & $500 \mathrm{~m}$ \\
Sensitivity 4 & $1000 \mathrm{~m}$ \\
Sensitivity 5 & $5000 \mathrm{~m}$ \\
Sensitivity 6 & $10000 \mathrm{~m}$ \\
\hline
\end{tabular}



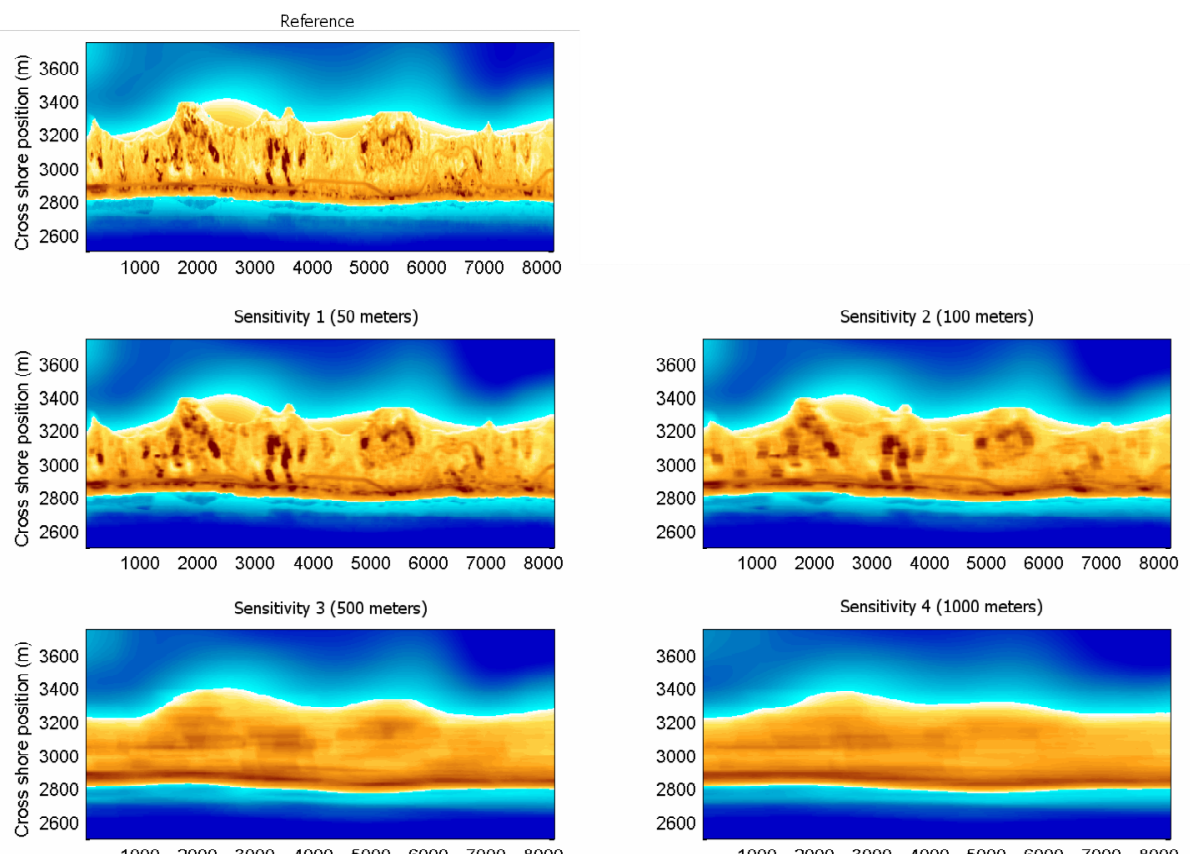

Sensitivity 5 (5000 meters)
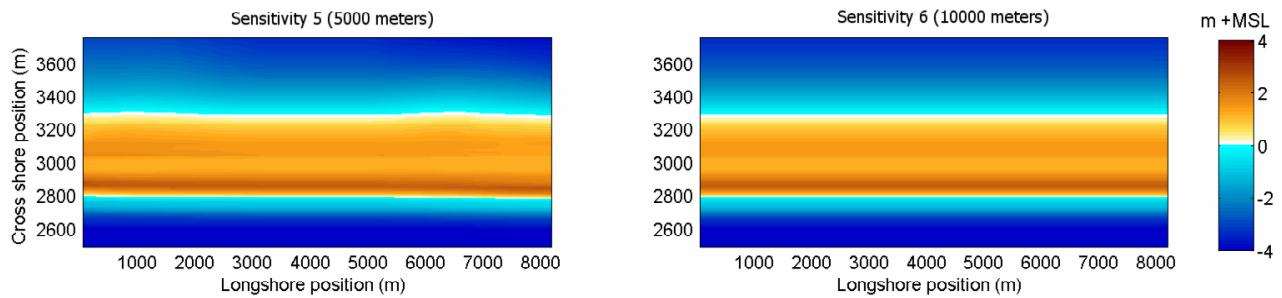

Figure 5: Initial bed elevation of the reference simulation and six sensitivity simulations.

\section{Hydraulic boundary conditions}

No nearshore or shallow water in-situ wave measurements exist for the study area on Santa Rosa Island during Hurricane Ivan with which to force the XBeach model. For this reason the base parametric hydraulic boundary conditions derived by McCall et al. (2010) for Hurricane Ivan at the same site are used in this study. These boundary conditions describe a 36-hour storm, with a maximum significant wave height of $7.0 \mathrm{~m}$ and maximum surge level of $1.75 \mathrm{~m}+\mathrm{MSL}$, see Figure 6. 


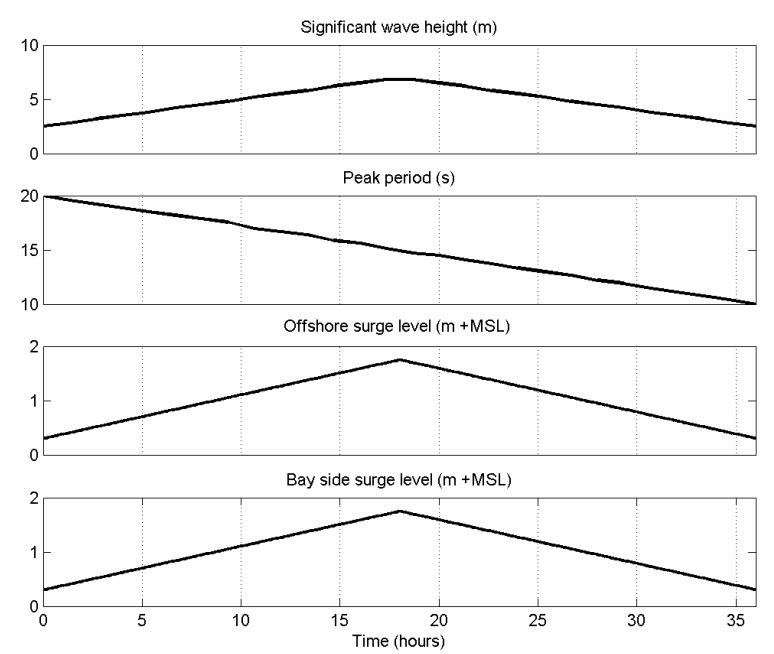

Figure 6: Imposed significant wave height (first panel) and peak wave period (second panel) on the offshore boundary and still water surge level on the offshore (third panel) and bay side boundary (fourth panel).

\section{MODEL RESULTS}

The measured pre- and post-storm bed level and bed level change are shown in Figure 7, along with the pre- and post-storm bed level and bed level change calculated in the reference simulation. The figure shows that in the reference simulation the patterns of erosion and deposition across the barrier island are well reproduced. The simulation produces the correct amount of erosion on the foredunes and the development of washover fans on the back barrier and in the back barrier bay. A point-bypoint comparison of the measured bed level change and modeled bed level change shows that the model has considerable quantitative skill, see Table 2.
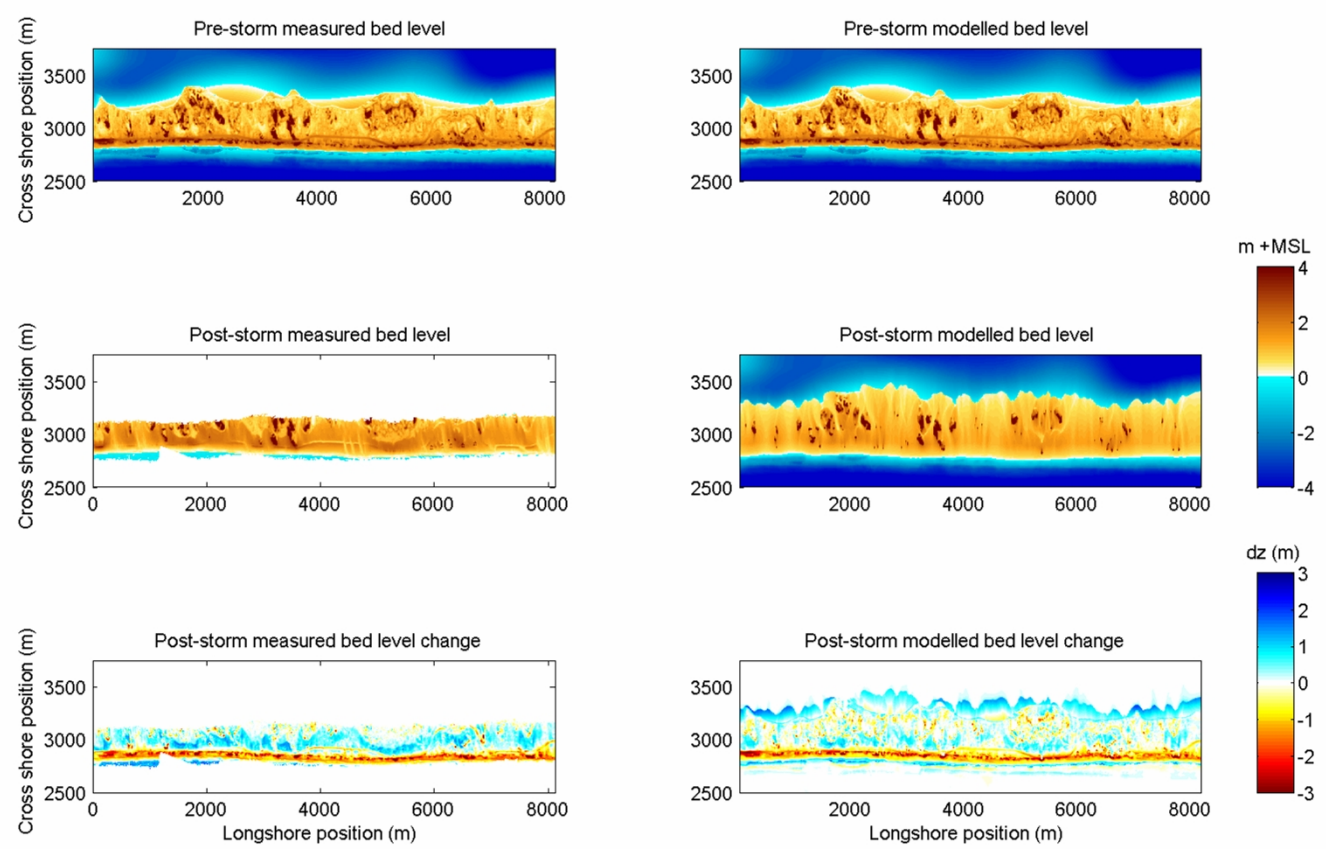

Figure 7: Measured and modeled pre-storm bed level (top row), post-storm bed level (centre row) and areas of erosion (red) and deposition (blue) after Hurricane Ivan (bottom row) for the reference simulation. 


\begin{tabular}{|c|c|}
\hline \multicolumn{2}{|c|}{ Table 2: Model skill and bias of the reference simulation } \\
\hline Skill (Gallagher et al., 1998) & 0.712 \\
Bias & $-0.136 \mathrm{~m}$ \\
\hline
\end{tabular}

The calculated bed level changes in the reference simulation and the sensitivity simulations are shown in Figure 8. The results show that the differences in morphological response between the six sensitivity simulations vary in the cross shore profile of the barrier island. The morphological response of the foreshore and foredune area remains relatively constant between simulations, with a similar amount of erosion on the foredunes and deposition on the foreshore. As the longshore filtering distance increases beyond 100 meters, the patterns of erosion and deposition on the back barrier start to change and erosion starts to dominate. The location and magnitude of washover fans remains constant between the reference simulation and the sensitivity simulations up to a longshore filtering distance of 100 meters. With longshore filtering distances greater than 100 meters a washover terrace is created in the back barrier bay instead of individual washover fans.
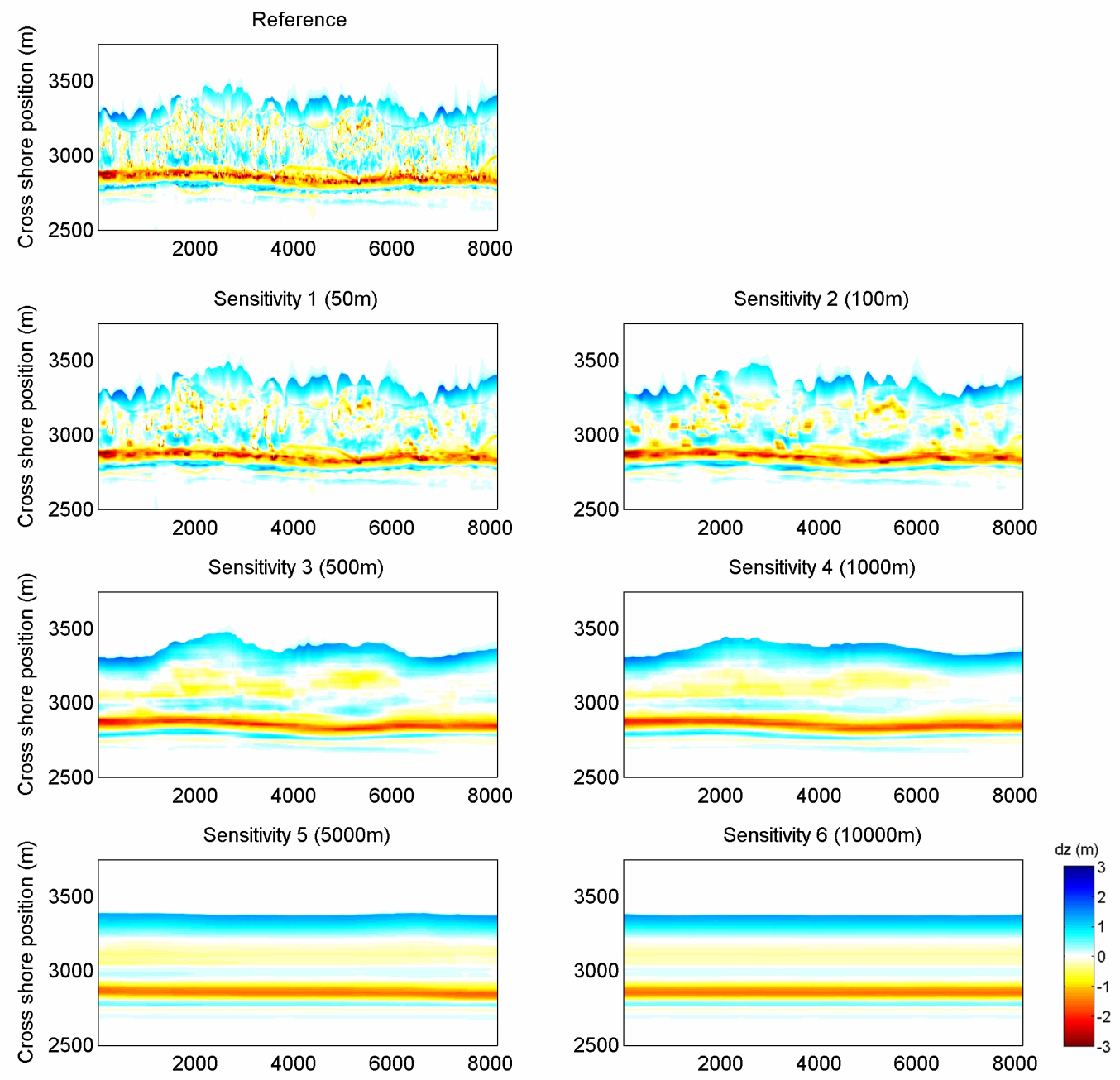

Figure 8: Post-storm simulated patterns of erosion (red) and deposition (blue) in the reference simulation and sensitivity simulations.

The differences between the sensitivity simulations in the morphological response on the back barrier can be explained by variations in the hydrodynamics across the barrier island. Figure 9 shows the average velocity on the barrier island during ten hours of inundation overwash in the reference simulation and three sensitivity simulations. The figure shows that the flow across the island in the 
reference simulation and the 100-meter filter sensitivity simulation is blocked by large scale features on the back barrier and only reaches the back barrier bay through six channels between the features on the back barrier. Although the average velocity in the channels is high, the majority of the back barrier experiences low flow velocities. In the sensitivity simulations with longer longshore filter distances the flow is not blocked by back barrier features. The resulting flow is high across the whole of the back barrier.
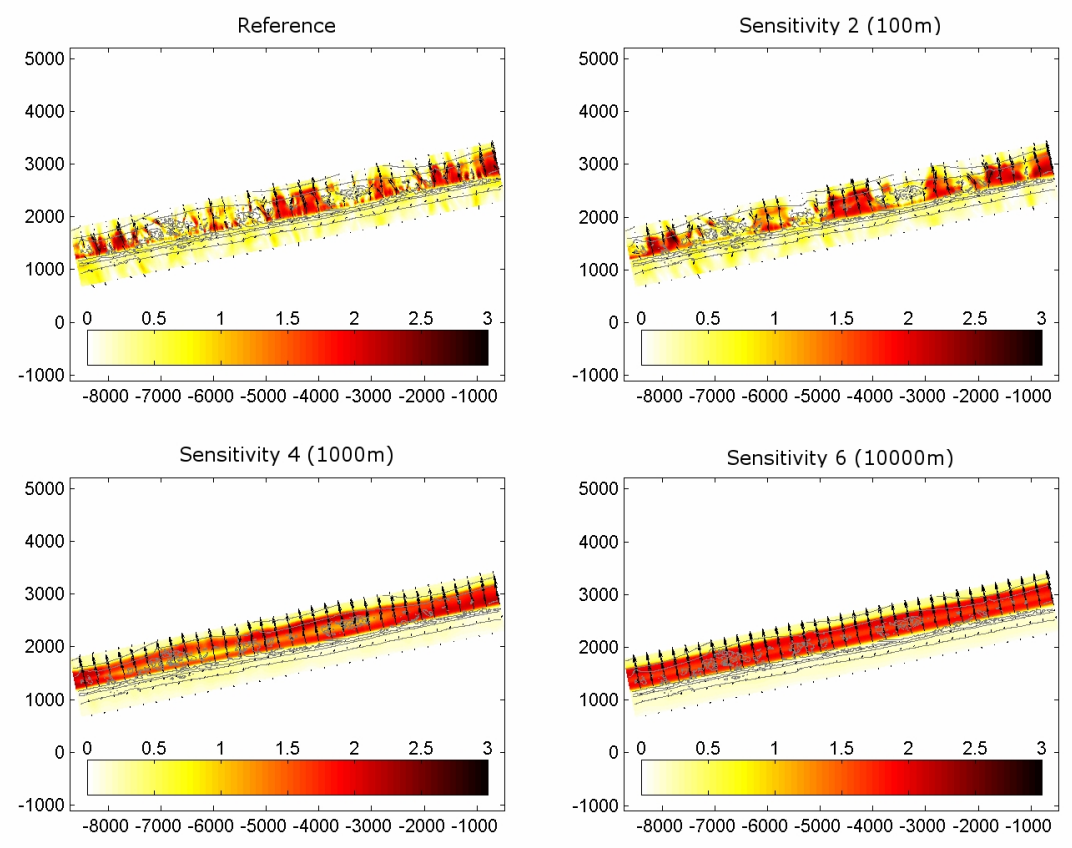

Figure 9: Average velocities across the barrier island during inundation overwash in the reference simulation and three sensitivity simulations. The grey contour lines show the measured pre-storm elevation.

The total erosion and deposition simulated by the reference simulation and the sensitivity simulations in the foreshore-foredune area, on the back barrier and in the back barrier bay is shown in Figure 10. The figure confirms that the total erosion in the foreshore-foredune area remains constant for all longshore filtering scales. The amount of deposition on the back barrier bay decreases significantly when the longshore filtering distance increases beyond 100 meters. As a result of the decreased amount of deposition on the back barrier, the amount of deposition in the back barrier bay increases if the longshore filtering distance increases beyond 100 meters. 

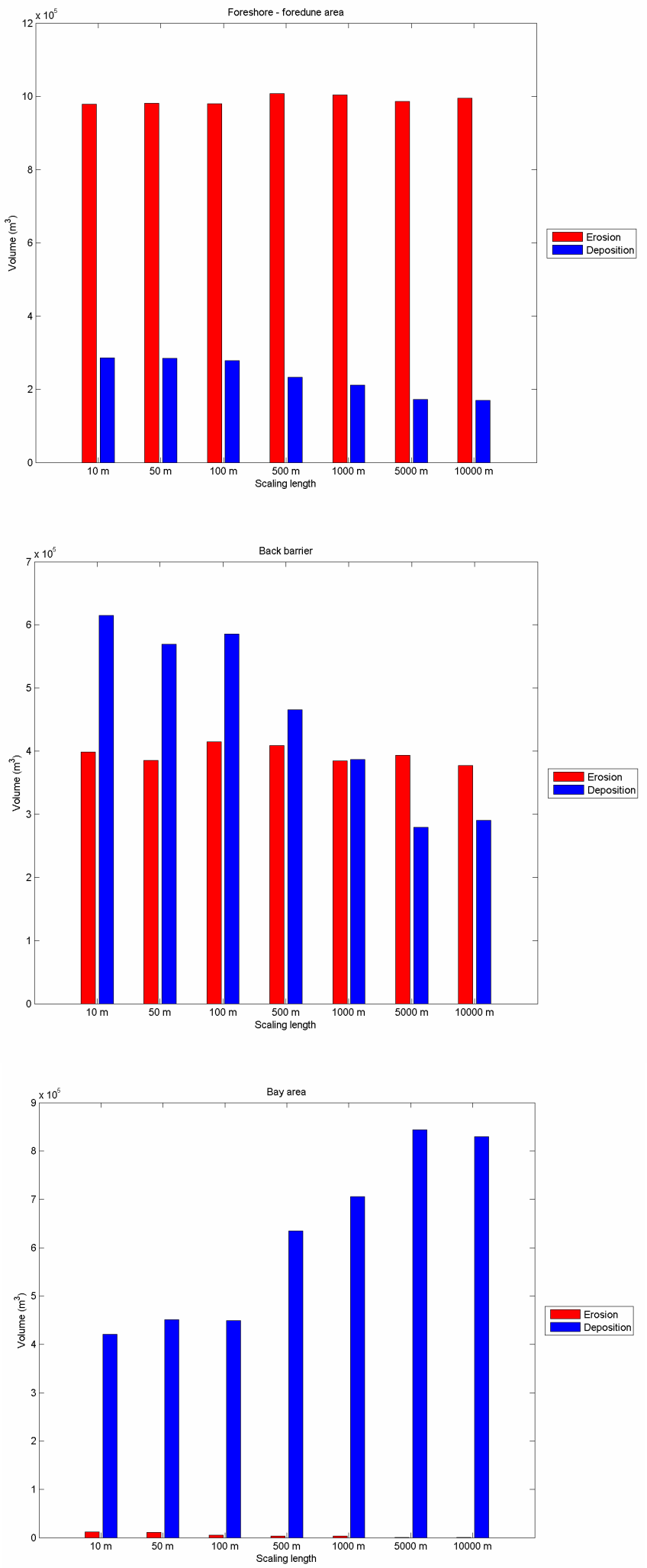

Figure 10: Total erosion (red) and deposition (blue) in the foreshore-foredune area (top panel), on the back barrier (center panel) and in the back barrier bay (bottom panel) for the reference simulation and the sensitivity simulations. 


\section{CONCLUSIONS}

We have described an application of the XBeach model to investigate the effect of longshore topographic variance on overwash. In this study the model was used to simulate the morphological response of an eight-kilometer section of Santa Rosa Island, Florida, due to Hurricane Ivan (2004). The influence of longshore scales in the bed elevation was investigated by comparing the morphological response of the reference simulation to the morphological response of six sensitivity simulations in which the initial bed elevation was modified to remove longshore topographic variance.

This study has shown that the XBeach model is capable of simulating spatially varying overwash patterns that are dependent on the initial bed elevation. It is shown that the morphological response of the foreshore-foredune area to Hurricane Ivan is not influenced strongly by the initial longshore bed variance. The morphological response of the back barrier and the back barrier bay to Hurricane Ivan is influenced by features on the back barrier with longshore length scales of 100-500 meters, which hamper the flow across the island during inundation overwash. If these large features are removed from the initial bed elevation, the amount of deposition on the back barrier decreases and more sediment is moved to the back barrier bay.

In this study the importance of longshore topographic variance at small length scales on the morphological response of the barrier island is relatively small compared to the influence of topographic variance in length scales greater than 100 meters. However, this may be a result of the magnitude of the storm forcing. It is recommended to examine further the effect of longshore topographic scales in situations with less extreme runup overwash conditions.

\section{ACKNOWLEDGMENTS}

The Research reported in this document has been made possible through the support and sponsorship of the U.S. Government through its European Research Office of the U.S. Army., under Contract no. N62558-06-C-2006 and through the European Community's Seventh Framework Programme under grant agreement $n^{\circ} 202798$ (MICORE Project). The USGS Coastal and Marine Geology Program provided support via the National Assessment of Coastal Change Hazards Project and Cooperative Agreement number 06WRAG0045.

\section{REFERENCES}

Andrews, D.G. and McIntyre, M.E., 1978. An exact theory of nonlinear waves on a Lagrangian-mean flow. Journal of Fluid Mechanics, 89(4): 609-646.

Brock, J.C., Wright, C.W., Sallenger, A.H., Krabill, W.B. and Swift, R.N., 2002. Basis and methods of NASA airborne topographic mapper lidar surveys for coastal studies. Journal of Coastal Research, 18(1): 1-13.

Deigaard, R., 1993. A note on the three-dimensional shear stress distribution in a surf zone. Coastal Engineering, 20: 157-171.

Department of Environmental Protection State of Florida, 2004. Hurricane Ivan Report: Beach and dune erosion and structural damage assessment and post-storm recovery plan for the Panhandle Coast of Florida, Tallahassee, Florida.

Divins, D.L. and Metzger, D., 2008. NGDC Coastal Relief Model, http://www.ngdc.noaa.gov/mgg/coastal/coastal.html.

Dolan, R. and Hayden, B., 1981. Storms and shoreline configuration. Journal of Sedimentary Petrology, 51(3): 737-744.

Donnelly, C., Kraus, N. and Larson, M., 2006. State of Knowledge on Measurement and Modeling of Coastal Overwash. Journal of Coastal Research, 22(4): 965-991.

Feddersen, F., Guza, R.T., Elgar, S. and Herbers, T.H.C., 2000. Velocity moments in alongshore bottom stress parameterizations. Journal of Geophysical Research, 105(C4): 8673-8686.

Galapatti, R. and Vreugdenhil, C.B., 1985. A depth-integrated model for suspended sediment transport. Journal of Hydraulic Research, 23(4): 359-377.

Gallagher, E.L., Elgar, S. and Guza, R.T., 1998. Observations of sand bar evolution on a natural beach. Journal of Geophysical Research, 90: 3203-3215.

Goda, Y., 1985. Random Seas and Design of Maritime Structures. University of Tokyo Press, Tokyo. 
Godfrey, P.J. and Godfrey, M.M., 1973. Comparison of ecological and geomorphic interactions between altered and unaltered barrier island systems in North Carolina. In: D.R. Coates (Editor), Coastal Geomorphology. State Univ. New York, New York, pp. 239-258.

Holthuijsen, L.H., Booij, N. and Herbers, T.H.C., 1989. A Prediction Model for Stationary, Shortcrested Waves in Shallow Water with Ambient Currents. Coastal Engineering, 13: 23-54.

Hosier, P.E. and Cleary, W.J., 1977. Cyclic Geomorphic Patterns of Washover on a Barrier Island in Southeastern North Carolina. Environmental Geology, 2(1): 23-31.

McCall, R.T. et al., 2010. Two-dimensional time dependent hurricane overwash and erosion modeling at Santa Rosa Island. Coastal Engineering, 57: 668-683. doi:10.1016/j.coastaleng.2010.02.006.

Plant, N.G., Holland, K.T. and Puleo, J.A., 2002. Analysis of the scale of errors in nearshore bathymetric data. Marine Geology, 191: 71-86.

Reniers, A.J.H.M., 1999. Longshore current dynamics, Delft University of Technology, Delft.

Reniers, A.J.H.M., Roelvink, J.A. and Thornton, E.B., 2004. Morphodynamic modeling of an embayed beach under wave group forcing. Journal of Geophysical Research, 109(C01030).

Roelvink, J.A., 1993. Dissipation in random wave groups incident on a beach. Coastal Engineering, 19: $127-150$.

Roelvink, J.A. et al., 2009. Modeling storm impacts on beaches, dunes and barrier islands. Coastal Engineering, 56: 1133-1152.

Soulsby, R., 1997. Dynamics of marine sands. Thomas Telford Publications, London.

Stelling, G.S. and Duinmeijer, S.P.A., 2003. A staggered conservative scheme for every Froude number in rapidly varied shallow water flows. International Journal for Numerical Methods in Fluids, 43(12): 1329-1354.

Suter, J.R., Nummedal, D., Maynard, A.K. and Kemp, P., 1982. A process-reponse model for hurricane washovers, 18th Coastal Engineering Conference, Capetown, pp. 1459-1789.

Svendsen, I.A., 1984. Wave heights and set-up in a surf zone. Coastal Engineering, 8: 303-329.

van Rijn, L.C., 1993. Principles of sediment transport in rivers, estuaries and coastal seas. Part I: Edition 1993. Aqua Publications, Amsterdam.

van Thiel de Vries, J.S.M., 2009. Dune erosion during storm surges. PhD Thesis, Delft University of Technology, Delft. 